\title{
Hackathon as a way to raise awareness and foster innovation for stroke
}

\author{
Hackathon como uma maneira de aumentar a conscientização e promover a inovação no AVC
}

Li Min Li, $i^{1,2,3}$ Sharon Johnson ${ }^{1}$

\begin{abstract}
The "Time is Brain" concept has been a major focus in the World Stroke Awareness Campaign. Objective: We describe our experience with a Hackathon (junction of hack+marathon), a 24 hour event of innovation- and technology-based project development, focused around detecting stroke. Method: The Hackathon was held during a Brazilian Student's union (BRASA) congress involving students from engineering and other technological disciplines. Results: Four teamscompleted the 24-hour challenge; two teams opted the stroke challenge. One team proposed improving detection using a mobile sensor Fit-Bit combined with a smart-phone to contact emergency dispatch. The other team developed a game, in which kids would play a role as a neurologist; to diagnosis stroke with objective to increase awareness. Conclusion: Hackathons can focus attention on innovation and improvement opportunities to support the World Stroke Campaign, as well as other campaigns to raise awareness for other health or social problems.
\end{abstract}

Keywords: stroke, innovation, hackathon, awareness campaign.

\section{RESUMO}

O conceito ‘Tempo é Cérebro “tem sido um grande foco na Campanha Mundial de conscientização sobre AVC. Objetivo: Nós descrevemos experiência com Hackathon (junção das palavras hack+marathon), um evento de 24 horas voltado a desenvolvimento de inovação tecnológica, centrada em torno de detecção de AVC. Método: O Hackathon aconteceu durante o congresso da Associação de Estudante Brasileiros no Exterior (BRASA), envolvendo estudantes de engenharia e disciplinas tecnológicas. Resultados: Quatro equipes completaram o desafio, duas optaram pelo desafio sobre AVC, uma propôs a detecção usando um sensor Fit-Bit e um telefone móvel para detecção e contato com a emergência. A outra equipe desenvolveu um jogo para as crianças detectarem AVC. Conclusão: Hackathon pode focar a atenção em inovações e oportunidades de melhorias como um adicional a Campanha Mundial contra AVC, bem como em outras campanhas de conscientização para outras doenças ou problemas sociais.

Palavras-chave: AVC, inovação, hackathon, campanha de conscientização.

The World Stroke Campaign is a global effort to bring awareness about the burden of stroke, with activities scheduled annually on October 29th ${ }^{1}$. The campaign often has relied on traditional educational approaches, including lectures and media engagement. More creative approaches to attract attention have also been tried, such as celebrity endorsement, running/walking events, soccer events, musical concerts, and car races. Every year, the movement generates more attention worldwide, and the Brazilian Stroke Network ${ }^{2}$ demonstrates this progress clearly.

Campaigns are mostly carried out by professionals from the academy, which have attracted students to the cause. Student involvement creates an opportunity to educate future professionals, who will influence their future work and civic environments and generate ongoing momentum. Yet while the number of student associations participating has increased over the years, most are focused on health science. Ideally, other students would also be involved, because increasingly the model for addressing health issues is based on a multidisciplinary approach.

We are overwhelmed with advanced technology, gadgets and mobile apps today, with countless possibilities for their applications in the health industry, from nanotechnology to semiconductors to Cloud technologies. In this fast-paced technological environment, high-tech companies and more recently science organizations have sought to develop

\footnotetext{
${ }^{1}$ Robert A. Foisie School of Business, Worcester Polytechnic Institute, Worcester MA, USA;

${ }^{2} U$ Mass Medical School, Department of Psychiatry, Worcester MA, USA;

${ }^{3}$ Universidade Estadual de Campinas, Faculade de Ciências Médicas, Campinas SP, Brazil;

Correspondence: Li Li Min; UNICAMP; Rua Zeferino Vaz, s/n; 13083-887 Campinas, SP Brasil; E-mail: limin@fcm.unicamp.br

Conflict of interest: There is no conflict of interest to declare.

Received 29 June 2015; Received in final form 29 July 2015; Accepted 19 August 2015.
} 
innovative ideas and solutions through hackathon. The term hackathon is formed from the junction of two words; hack (not in the criminal sense) and marathon; it is an event often lasting for 24 hours, where participants are challenged collectively to solve a problem though programming or other technological approaches. In the neurology community, we have recently seen hackathons hosted by the brain imaging consortium $^{3,45}$ to look for ways to improve imaging analysis. In this article, we describe our experience with a hackathon involving the challenge of how to detect stroke. One goal was to include students from engineering and other disciplines, rather than students with a health science focus.

\section{METHOD}

This article is an observational and descriptive report of a hackathon. The study was not submitted to the Ethics Committee, as it is a description of activities during a public event. The facts were described with as much objectiveness as possible; nevertheless, we recognize the bias in this qualitative approach. The general experience, however, is singular and of interest to the scientific community, because we believe that it can support future stroke campaigns as well be adapted to other neurological diseases.

The setting was the BRASAtech meeting organized by Brasa (Brazilian Students Association) on the October $31^{\text {st }}$ to November $1^{\text {st }}, 2014$. BRASAtech is the first nationwide Brazilian conference held in the United States, at Worcester Polytechnic Institute, with Science and Technology as its core. The meeting was organized into two parts; a conference and a hackathon. The participants were mostly Brazilian undergraduate or graduate students attending universities across the United States. BRASATech's Hackathon ${ }^{6}$ provided the participants a unique chance to contribute to Brazil's future by designing and implementing a software application to solve a real-world problem. The problem was kept secret and disclosed on the day of the event. Participants were challenged to develop innovative software, technology, prototypes or proofs of concept that would improve issues faced in Brazil. Each participant could choose from one of three challenges, two focused on education issues (grading and preparing assessments) and the third on stroke, the leading cause of death in Brazil and worldwide. The rationale of the stroke challenge was provided to participants the following way:

Stroke can be effectively treated. For instance, ischemic stroke, the most common type of stroke (80\%) can be treated with medication to dissolve the clot. The best result is seen in those treated within 90 minutes from the onset of the stroke. Unfortunately, less than $30 \%$ of patients with stroke arrive within 60 minutes to the hospital ${ }^{8}$. The reasons for the delay in looking for help varies, from lack of knowledge in recognizing the stroke signs, denial to cognitive impairment to access help. Therefore, a device that can help detect stroke, monitor vital signs and rule out stroke mimics such as hypoglycemia, and connect with emergency medical services can improve the chances of patients survival. Time is Brain. Act Now!

Challenge: To detect Stroke, to monitor and to connect to Emergency Medical Service. The prize for the winner was 2,000.00 US dollars.

A crash course on stroke (20 minutes) was given to the participants by the first author (LML) using the World Stroke Campaign teaching material.

The competitors worked in groups and had 24 hours to hack and to pitch their case in a 5 minute presentation describing the social relevance, proposed solution, added value and business plan, follow by a 5 minute discussion with a panel of judges and the public.

\section{RESULTS}

Four teams, of three to four students each, completed the 24 hour hackathon challenge. Two teams chose stroke as their challenge. The team "Safe Life" proposed a solution using available technologies, including a smart phone and fit bit, to collect information on health status such as blood pressure and to store patient patterns. If readings fell outside the pattern, there would be an alarm to check on status and screen for stroke, which if confirmed would initiate a call to emergency dispatch. The team "Go Now, Go Fast" chose to pursue an internet-based platform to develop a program to raise awareness through a game for children, where children can act as neurologists and play a role in the stroke game. Neither team produced a prototype or a beta version of the project.

\section{DISCUSSION}

The overall experience with the hackathon for stroke was positive, as a strategy for promoting stroke awareness as well as for discussing innovation and technology $9,10,11,12$. The proposed problem of speeding the access to treatment for patients with stroke is a real challenge ${ }^{13}$. The 24-hour projects presented were based on technology available today. One project made use of current mobile and smart phone capabilities; it is just a matter time before these technologies are effectively combined with integrated logistics systems, including people's daily use of ASIS or GoogleMaps. This approach has been applied also to detect seizure in epilepsy ${ }^{14}$. Such technologies offer the promise of significantly increasing the number of patients arriving in the optimal treatment window (under 90 minutes). The other proposal brought up a more engaging means of conveying important information to children through a game. Educational games are a powerful way to support the teaching-learning process. As matter of fact, we have seen several applications related to stroke ${ }^{9}$, as we should see them perfected in the coming years. 
Focusing on organizational aspects, the hackathon was part of a student union meeting. Brasa ${ }^{15}$ is a newly constituted nationwide Brazilian student organization with a mission "to create platforms through which US students can engage with Brazil, inspiring them to contribute to the development of the country". Fewer than $5 \%$ of Brazilian students can currently pursue an international higher educational experience, and these students are likely to chair important organizations in the future. The Brazilian government has committed to a globalization effort through a Program Science without Borders $^{16}$ by offering scholarship to Brazilian students to experience different academic, research and culture perspectives. We believe that student associations such as BRASA provide important support for such programs, as challenges like the hackathon forces them to think about applications for their own countries based on their realities. In addition, students pursuing technical degrees are given the opportunity to see how their work applies to important societal problems, such as education and health care.
In summary, events like the hackathon can focus attention on innovations and improvement opportunities to support the World Stroke Campaign, as well as campaigns that raise awareness for other health and societal problems. A word of caution for organizers, who must understand that the good intentions attached to hackathon require effort beyond its end for funding solutions ${ }^{17}$. Yet a hackathon is a unique event that fosters learning, harnesses a spirit of collaboration, and develops a network of engaged individuals who can respond to challenges yet to come.

\section{Acknowledgements}

We would like to thank Matheus Augusto Silva, president of BRASA (Brazilian Student Association) and Fernando Coelho, coordinator of BRASAtech Hackathon for embracing the World Stroke Campaign 2014. Li Li Min is recipient of FAPESP scholarship 2014/10911-3

\section{References}

1. World Stroke Campaign. Why act now? [Internet]. [S.l.]: World Stroke Organization [cited 2014 Oct 16]. Available from: http://www. worldstrokecampaign.org/about-the-world-stroke-campaign/whyact-now.htm

2. Rede Brasil AVC [Internet]. Porto Alegre: Rede Brasil AVC [cited 2014 Nov 7]. Available from: http://www.redebrasilavc.org.br/

3. Organization for Human Brain Mapping. HBM Hackathon [Internet]. Minneapolis: Humanbrainmapping.org [cited 2014 Nov 4]. Available from: http://humanbrainmapping.org/hackathon

4. Allen Institute for Brain Science. 2012 Allen brain atlas hackathon [Internet]. [S.L.]: Community.brain-map.org; 2012 [cited 2014 Nov 4]. Available from: http://community.brain-map.org/display/hackathon/ 2012+Allen+Brain+Atlas+Hackathon

5. Neurosynth Hackathon, 2014 May 23-26, Boulder, Colorado [Internet]. [cited 2014 Nov 4]. Available from: http://hackathon.neurosynth.org/

6. BRASATech Hackathon [Internet]. New York: ChallengePost [cited 2014 Nov 7]. Available from: http://brasatech.challengepost.com/

7. Lees KR, Bluhmki E, Kummer R, Brott TG, Toni D, Grotta JC et al. Time to treatment with intravenous alteplase and outcome in stroke: an updated pooled analysis of ECASS, ATLANTIS, NINDS, and EPITHET trials. Lancet. 2010;375(9727):1695-703. doi:10.1016/S0140-6736(10)60491-6

8. Saver JL, Smith EE, Fonarow GC, Reeves MJ, Zhao X, Olson DM et al. The "golden hour" and acute brain ischemia: presenting features and lytic therapy in $>30,000$ patients arriving within 60 minutes of stroke onset. Stroke. 2010;41(7):1431-9. doi:10.1161/STROKEAHA.110.583815
9. Dubey D, Amritphale A, Sawhney A, Amritphale N, Dubey P, Pandey A. Smart phone applications as a source of information on stroke. $J$ Stroke. 2014;16(2):86-90. doi:10.5853/jos.2014.16.2.86

10. Bladin CF, Cadilhac DA. Effect of telestroke on emergent stroke care and stroke outcomes. Stroke. 2014;45(6):1876-80. doi:10.1161/STROKEAHA.114.003825

11. Chandrasekaran V, Dantu R, Jonnada S, Thiyagaraja S, Subbu KP. Cuffless differential blood pressure estimation using smart phones. IEEE Trans Biomed Eng 2013;60(4):1080-9. doi:10.1109/TBME.2012.2211078

12. Mans R, Schonenberg H. Process mining techniques: an application to stroke care. Stud Health Technol Inform. 2008;136:573-8.

13. Ragoschke-Schumm A, Walter S, Haass A, Balucani C, Lesmeister $\mathrm{M}$, Nasreldein A et al. Translation of the "time is brain" concept into clinical practice: focus on prehospital stroke management. Int J Stroke. 2014;9(3):333-40. doi:10.1111/ijs.12252.

14. Dolgin E. Technology: dressed to detect. Nature. 2014;511(7508):S16-7. doi:10.1038/511S16a

15. Brazilian Student Association - Brasa [Internet]. [cited 2014 Nov 7] Available from: http://www.gobrasa.org/

16. Science without Borders. The program [Internet]. Brasilia, DF: Ministério da Ciência, Tecnologia e Inovação, Ministério da Educação [cited 2014 Nov 7]. Available from: http://www.cienciasemfronteiras.gov.br/web/csf-eng/

17. Matias JN. Media-making strategies to support community and learning at hackathons [Internet]. Cambridge: MIT Center for Civic Media; 2014 [cited 2014 Nov 4]. Available from: https://civic.mit.edu/ blog/natematias/media-making-strategies-to-support-communityand-learning-at-hackathons 